\title{
Mulheres evangélicas na política: tensionamentos entre o público e o privado
}

\author{
Evangelical women in politics: stress between public and private
}

Sandra Duarte de Souza*

\begin{abstract}
Resumo
A baixa representatividade feminina no Congresso Nacional brasileiro tem sido recorrentemente criticada pelos movimentos feministas, por agências internacionais e pelas próprias parlamentares. Dos 513 parlamentares eleitos para a 55a legislatura, 51 são mulheres, e destas, dez se declaram evangélicas. A atuação de mulheres evangélicas na política não tem sido objeto de interesse da academia, seja no âmbito dos estudos de religião ou dos estudos feministas. O presente artigo aborda a atuação das parlamentares evangélicas na política brasileira atual, considerando-se a tímida participação feminina na política partidária, o processo de inserção dos evangélicos na política, e o lugar invisível das deputadas evangélicas no fazer político de suas legendas, inclusive em pautas diretamente relacionadas com os direitos das mulheres. Tal abordagem tem sua base teórica na discussão da dicotomia público/privado, partindo do pressuposto de que existe uma interdependência entre ambos, e de que o incômodo social com a presença das mulheres na esfera pública tem a ver com a generificação e consequente hierarquização de tais esferas. Como recurso metodológico, procedeu-se ao levantamento das proposições das dez deputadas em seus seis primeiros meses de mandato na atual legislatura, e também das proposições da legislatura anterior, no caso das deputadas reeleitas.
\end{abstract}

Palavras-chave: mulheres evangélicas; política; gênero; público/privado.

\begin{abstract}
The low representation of women in the Brazilian National Congress has been recurrently criticized by the feminist movements, international agencies and the parliament representatives themselves. From the 513 parliament representatives elected for the 55th legislation, 51 are women representatives, and only 10 of these are evangelical Christians. The acting of evangelical women in politics has not been a subject of interest by the academy in the field of religious and feminist studies. The present article addresses the acting of evangelical women representatives in the current Brazilian politics, taking in consideration the timid participation of women in political parties, the process of evangelical insertion into Brazilian politics and the invisible place of evangelical women on political acting in their parties, including on Legislative drafting related to the right of women. Such an approach has its theoretical basis in discussion of the public/private dichotomy, on the assumption that there is an interdependence between them, and that the social nuisance with the presence of women in the public sphere has to do with the genderization and subsequent hierarchization of such spheres. As a methodological resource, there was made a recollection of the drafts proposals of the 10 evangelical women representatives on their 6 first months of mandate during the current legislation, and also of the draft proposals during the former legislation of the reelected ones.
\end{abstract}

Keywords: evangelical women; politics; gender; public/private.

Artigo recebido em 19 de junho de 2015 e aprovado em 21 de setembro de 2015.

* Doutora em Ciências da Religião pela UMESP. Professora do Programa de Ciências da Religião da Universidade Metodista de São Paulo e coordenadora do Grupo de Estudos de Gênero e Religião Mandrágora/Netmal. País de origem: Brasil. E-mail: sanduarte3@gmail.com

Horizonte, Belo Horizonte, v. 13, n. 39, p. 1261-1295, jul./set. 2015 - ISSN 2175-5841 


\section{Introdução}

A esfera política, considerada "lugar de homem", tem sido uma das mais herméticas à participação feminina em todo o mundo. O recente episódio ocorrido na Câmara dos Deputados, envolvendo a Deputada Jandira Feghali e os deputados Roberto Freire e Alberto Fraga, exemplifica essa postura. Durante a sessão de debate das medidas provisórias do ajuste fiscal, o deputado Roberto Freire empurrou Jandira Feghali ${ }^{1}$, e essa o acusou publicamente. Durante o embate, Alberto Fraga foi à tribuna e falou ao microfone: "eu digo sempre que mulher que participa da política e bate como homem, tem que apanhar como homem também” (PASSARINHO; ALEGRETTI, 2015). Fraga sintetiza a opinião de um contingente significativo de políticos e de eleitores em relação à presença pública das mulheres, em especial no campo da política. A expressão "mulher que participa da política” sugere que as mulheres seriam um sujeito estranho a esse universo, e para manterem-se nele teriam que atuar "como homens", isto é, "bater" e "apanhar como homem”, apelando para os estereótipos de gênero dominantes na sociedade.

Se o hermetismo da política partidária à participação feminina se apresenta como um obstáculo à superação das desigualdades de gênero, outro aspecto que se soma a esse é o fato de que, quando na política, as mulheres em sua maioria não têm estado à frente de comissões ou grupos de trabalho que têm incidência direta sobre temas relativos às desigualdades de gênero. A disputa política que tem ocorrido no país em torno dos direitos sexuais e reprodutivos, por exemplo, revela que os direitos das mulheres têm sido debatidos e negociados por homens que apelam com frequência para argumentos religiosos na tentativa de evitar a aquisição de novos direitos e também de retroceder em relação a direitos já adquiridos. Um dos segmentos políticos mais militantes nessa disputa é a Frente Parlamentar Evangélica (FPE), que tem se destacado especialmente nos dois

\footnotetext{
${ }^{1}$ Roberto Freire admitiu que empurrou a deputada, e disse "pode até ter sido um pouco com força", tendo se desculpado posteriormente (PASSARINHO; ALEGRETTI, 2015).
} 
últimos pleitos eleitorais do país empunhando a bandeira da defesa da família, da moral e dos bons costumes.

A FPE reúne deputados e deputadas que se autodeclaram evangélicos e que em sua maioria afirmam ter uma ação política perpassada por essa identidade religiosa. A composição da Frente é majoritariamente de parlamentares vinculados a partidos identificados como de direita e de cunho conservador. Apesar de apresentar uma média de mulheres superior à média geral de participação feminina na Câmara de Deputados, a FPE tem se posicionado veementemente contra os direitos reprodutivos e sexuais, e tem sido uma das mais combativas contra o que denomina "ideologia de gênero" (SOUZA, 2014a). Na disputa por participação, presidência ou relatoria de comissões relativas a esses temas, os nomes indicados e apoiados pelos partidos com políticos vinculados à Frente, são frequentemente de homens, e nas próprias comissões criadas pela Frente, eles é que detêm a presidência.

É diante desse cenário que no presente artigo nos propomos a levantar e analisar em perspectiva de gênero a atuação das parlamentares vinculadas à Frente Parlamentar Evangélica.

\section{0 gênero da desigualdade no Brasil}

Para criticar essas teorias, que tentavam se livrar do problema da diferença sexual, impondo que se excluíssem as mulheres da cena política, foi que o feminismo encontrou sua instável raison d'être. (SCOTT, 2002, p.286).

A crescente atuação pública das mulheres no Brasil é cada vez mais evidente. As mulheres têm alcançado visibilidade na educação, no mercado de trabalho, na religião e na política. No âmbito da política, especialmente, o Brasil é um dos três países sul-americanos que já elegeu uma mulher para o cargo máximo de 
presidenta da República², sendo que nos últimos pleitos as candidatas têm se saído muito bem em termos de votação. No pleito de 2010, dentre os três candidatos com melhor intenção de votos, duas eram mulheres - Dilma Rousseff e Marina Silva, e na disputa final uma mulher, Dilma Rousseff, foi eleita. No pleito de 2014, mais uma vez, Marina Silva e Dilma Rousseff despontaram como candidatas que tinham a preferência do eleitorado dentre os três mais bem cotados no primeiro turno. $\mathrm{O}$ resultado das urnas no segundo turno, que envolveu a disputa entre Dilma Rousseff e Aécio Neves, foi a reeleição de Dilma.

Embora as mulheres representem a maioria da população brasileira (51,5\% IBGE) e, segundo o TSE, representem 52,3\% do eleitorado3, raramente exercem um cargo político eletivo. Um rápido olhar sobre a composição do Senado e da Câmara de Deputados, revela que a representação feminina nessas esferas não ultrapassa meros 13\% (Senado) e 9,9\% (na Câmara), e raramente essas mulheres estão à frente de comissões importantes que envolvem essas casas legislativas.

Algumas pesquisas demonstram a crescente aceitação social da presença feminina na política, como é o caso da pesquisa "Mulheres na Política", realizada pelo DataSenado em parceria com a Procuradoria da Mulher (2014). A coleta de dados junto a 1091 cidadãos e cidadãs com mais de 16 anos, revela que a maioria dos entrevistados (83\%) afirma que o sexo do candidato não faz diferença para a escolha do mesmo, e que $79 \%$ já votou em alguma mulher para ocupar um cargo político. Paradoxalmente, o número de mulheres que se envolvem com a política partidária é bastante baixo, e o Brasil, segundo a União Inter-Parlamentar (INTERPARLIAMENTARY UNION, 2015), está abaixo da média mundial, estando inclusive abaixo da média do Oriente Médio. A pesquisa do DataSenado aponta que a baixa representatividade das mulheres na política estaria relacionada à falta de apoio dos partidos políticos para candidatas. Nada menos que $41 \%$ das mulheres

\footnotetext{
2 De 1974-1976 a Argentina elegeu sua primeira presidenta, María Estela Martínez de Perón. O Chile elegeu Michelle Bachelet para governar o país de 2006 a 2010. Kristina Kirchiner é a presidenta da Argentina desde 2007, e Dilma Rousseff ocupa o cargo de presidenta desde 2010.

${ }^{3}$ TSE, 29 de julho de 2014.
} 
entrevistadas alegam principalmente que não se candidatam a cargo político porque os partidos não dão o suporte necessário para candidaturas femininas. O desinteresse pela política é o segundo maior motivo declarado (23\%) para o não investimento nessa área, e em terceiro lugar as entrevistadas alegaram ser difícil concorrer com homens (19\%). A pesquisa conclui que talvez um dos maiores obstáculos para a presença de mulheres na política brasileira sejam os próprios partidos políticos.

Certamente a falta de apoio dos partidos políticos para candidaturas femininas é um impedimento para a ampliação do quadro de mulheres na política, mas o substrato de gênero que perpassa as diferentes formas de legitimidade da prática política de homens e mulheres, e a recepção de tais práticas pela população em geral, indicam que o problema é mais denso do que as pesquisas pretendem demonstrar. O discurso da diferença dos sexos, como aponta Joan Scott, refere-se "às instituições, às estruturas, às práticas quotidianas, [...] aos rituais e a tudo que constitui as relações sociais" (GROSSI; HEILBORN; RIAL, 1998, p. 115). A diferença dos sexos informa e constitui o universo político e a definição de agentes legítimos e ilegítimos para a prática política.

Para Ana Alice Costa, à mulher se atribuiu

uma identidade vinculada ao privado, à subordinação, impedindo-a de constituir-se como sujeito político. Essa identidade, fruto de uma larga construção histórica, assumiu diversas formas e modalidades culturais específicas, de acordo com as necessidades do sistema de dominação patriarcal (COSTA, 1998, p. 205).

A resistência das mulheres ao enclausuramento no privado e sua afirmação como sujeitos políticos, desestabiliza esse sistema de abjeção à agência feminina, que reage, reafirmando o abjeto buscando garantir assim a sua regulação (Butler, 1993 e 2003). Talvez um dos exemplos mais recentes seja a reação de distintos segmentos sociais à atual crise político-econômica pela qual atravessa o país, tendo como consequência a reação à presidenta Dilma Rousseff, em especial. Apenas para 
citar um episódio, no dia 08 de março de 2015, por ocasião do Dia Internacional da Mulher, a presidenta fez um pronunciamento em rede nacional. Centenas de brasileiros e brasileiras, especialmente de classes mais favorecidas, mas não somente, se debruçaram nas janelas de suas residências ou de seus carros e realizaram um panelaço/buzinaço contra ela. Até aí, nada que não se faria em reação a qualquer governo. As palavras proferidas contra a presidenta nesse protesto, no entanto, são indicadores de quão objetivadas estão as representações de gênero na sociedade. "Vaca", "puta" e "arrombada" foram palavras gritadas por homens e mulheres de classes sociais e identidades étnico-raciais distintas e das mais diferentes idades. Considerando os aspectos de gênero que envolvem a associação predominante desses termos com a desqualificação das mulheres, vemos nessas manifestações uma crítica não apenas ao governo, mas à própria condição de mulher da presidenta.

A histórica associação das mulheres à sexualidade e o empreendimento cultural de afirmá-las nesse lugar, tem sido objeto da crítica feminista, que explicita a produção social de identidades rígidas e sua naturalização. O que se entende por masculino ou feminino é contextual, variando de sociedade para sociedade, de acordo com diferentes momentos da história (BUTLER, 2003).

Os papeis conferidos a homens e mulheres, o binarismo da diferença sexual, a naturalização e hierarquização dessa diferença (SCOTT, 1990), são mecanismos que legitimam a dominação de gênero, e são evocados no assédio sexual que as mulheres experimentam na família, na escola, no mundo do trabalho, na política e na religião; na prescrição de "trajes decentes" e do "manter-se em casa" para o evitamento do estupro ou para a diferenciação das "mulheres decentes" das "indecentes" e assim por diante.

O controle social dos corpos das mulheres as classifica e determina os espaços legítimos das mesmas. Isso talvez nos ajude a entender a reação raivosa dos manifestantes de 8 de março. Uma mulher pública nem sempre é vista como 
líder política. Na gramática de gênero do senso comum, mulher pública é sinônimo de "vaca”, "puta” e "arrombada”.

A teoria política moderna ressalta a dicotomia entre as esferas pública e privada, afirmando a separação entre razão e desejo, isto é, entre o que se considera da esfera pública, como a política e a racionalidade, e o que se considera da esfera privada, como a família e as emoções. Na normalização dessas esferas, o público é identificado como espaço dos homens, e o privado, como lugar das mulheres. Essa geografia de gênero não reconhece a legitimidade da presença pública das mulheres, daí o estranhamento social em relação à participação das mulheres na política.

\section{Entre o público e o privado: redefinindo geografias em perspectiva de gênero}

Cabe-me a honra, com minha simples presença aqui, de deixar escrito um capítulo novo para a história do Brasil - o da colaboração feminina para a história do país. Carlota de Queiroz (AZEVEDO; RABAT, 2012, p. 14).4

A ideia da separação e diferenciação entre público e privado tem sido perpetuada pela teoria política, e tem reproduzido a visão predominante de gênero à medida em que localiza as mulheres no privado e os homens no público, e estabelece uma hierarquia entre essas esferas, em que o público se sobressai ao privado. No campo dos Estudos Feministas, a crítica acerca da dicotomia públicoprivado se revela fundamental, e seus esforços têm sido no sentido de afirmar a interdependência entre público e privado (PATEMAN, 1993; OKIN, 2008). Para Hanna Pitkin (1981, p. 347-348), essa interdependência se verifica na forma como a esfera pública é afetada pela vida concreta dos indivíduos, corroborando o jargão de que "o pessoal também é político":

\footnotetext{
${ }^{4}$ Discurso de Carlota Pereira de Queiroz quando de sua posse como primeira deputada federal do Brasil em 13 de março de 1934.
} 
Aquilo que antes era aceito como um problema pessoal passa a ser visto como questão de interesse público, um problema de justiça. Nessa situação temos a dona de casa que descobre pela primeira vez que ela não está sozinha em sua miséria e tédio, que aquilo que a incomoda é parte de uma estrutura que pode ser alterada. 5

Como bem demonstra Susan Okin (2008, p. 314), a vida doméstica, pessoal, identificada como da esfera privada, não está isolada da vida não-doméstica, pública, que envolve economia e política. Na esfera doméstica se tecem relações de poder e se estruturam as relações econômicas, portanto, não se trata de um submundo isolado do contexto mais amplo.

Okin chama a atenção também para a persistência de um sistema de preconceito presente na dicotomia público/privado. Segundo ela, a divisão sexual do trabalho aloca os homens nas áreas econômica e política, enquanto as mulheres são alocadas no âmbito doméstico, incluindo-se aí a reprodução e os cuidados com a família. Dessa forma, "as mulheres têm sido vistas como 'naturalmente' inadequadas à esfera pública, dependentes dos homens e subordinadas à família" (OKIN, 2008, p. 308). Uma vez que público e privado não são entendidos apenas como esferas separadas, mas também como esferas que se opõem, a naturalização da habilidade das mulheres para a esfera doméstica, é também a naturalização da sua incompetência para a esfera pública. Tal compreensão nos ajuda a entender o histórico de oposições à participação política das mulheres, considerada como incompatível com a condição feminina.

Quando do processo constituinte de 1890, o direito das mulheres ao voto foi negado sob argumentos diversos. O deputado Barbosa Lima, por exemplo, opôs-se ao voto feminino porque, segundo ele, "a participação da mulher na vida pública abalaria os alicerces da família” (MACHADO NETO, 2000, p. 6). Esse argumento foi recorrente nas manifestações contrárias ao sufrágio universal. Outros

\footnotetext{
5 "What had been accepted as personal trouble comes to be seen as an actionable public issue, a matter of justice. Here we find the housewife who learns for the first time that she is not alone in her misery and boredom, that what troubles her is part of a social structure that can be altered" (PITKIN, 1981, p. 347-348). Tradução da autora.
} 
argumentaram que o voto das mulheres significaria "a dissolução da família brasileira” (ROURE, 1979, p. 233). Foram apresentadas algumas emendas por não mais de três deputados dos 21 que compunham a Comissão dos 21 do Congresso, que visavam reconhecer o direito cidadão de algumas mulheres ao voto, como as que possuíssem formação científica, fossem professoras e "que não estivessem sob o poder marital nem paterno, bem como às que estivessem na posse de seus bens" (ROURE, 1979, p. 277.). Outra emenda visava o direito ao voto de mulheres solteiras e viúvas, isto é, que não estivessem sob a tutela de maridos, desde que fossem "diplomadas em direito, medicina ou farmácia” ou que estivessem na direção de "estabelecimentos docentes, industriais ou comerciais" (ROURE, 1979, p. 272). Vê-se que se havia alguma possibilidade de no debate sobre o voto feminino se conseguir apoio de alguns poucos deputados, esse apoio era exclusivamente para mulheres brancas de classes mais abastadas e mais escolarizadas. Nenhuma das emendas foi aprovada.

Apesar de alcançarem o direito de votar e serem votadas desde $1932^{6}$, as mulheres sempre tiveram baixas taxas de representatividade nas casas legislativas. Carlota Pereira de Queiróz foi a primeira deputada federal, não apenas do Brasil, mas de toda a América Latina, tendo sido eleita para a Assembleia Constituinte de 1933 (AZEVEDO; RABAT, 2012, p. 10)7. A fotografia do plenário da Câmara com seus 214 deputados, e a solitária figura de Carlota Queiróz, ilustra muito bem a compreensão da época acerca da participação política de homens e mulheres:

\footnotetext{
${ }^{6}$ Há registros da participação política das mulheres antes disso, como no caso de Isabel de Mattos Dillon, que era dentista e reivindicou o direito ao voto, pois a legislação (Constituição Política do Império e Lei Saraiva) o garantia para portadores de títulos científicos, tendo conseguido seu alistamento eleitoral em 1880 (AZEVEDO; RABAT, 2012, p. 36). Também há registros da participação de mulheres como eleitoras na Comarca de Minas Novas-MG, desde 1906 (ALVES, 1980). Em 1927, em Mossoró-RN, quinze mulheres foram às urnas pela primeira vez, mas esses votos não foram contabilizados pelo Senado. Nesse mesmo ano, na cidade de Lages (RN), foi eleita a primeira prefeita do Brasil, Alzira Soriano de Souza.

${ }^{7}$ Mais duas mulheres concorreram, mas não foram eleitas: Bertha Lutz e Leolinda de Figueiredo Daltro.
} 


\section{Imagem 1 - Fotografia do Plenário da Câmara}

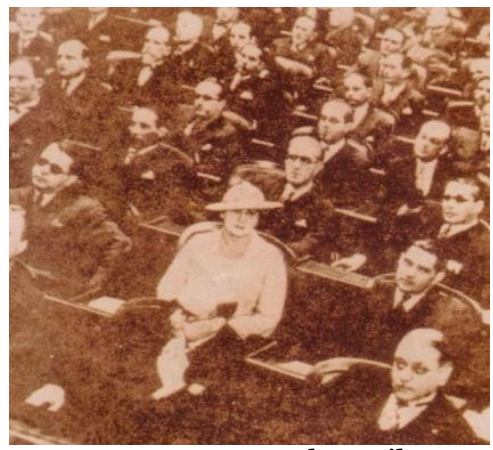

Fonte: BRASIL. Portal Brasil, 2010

Na legislatura de 1935-1937, além de Carlota Queiroz, que foi reeleita, Bertha Lutz, que era suplente de Cândido Pessoa, também assumiu como deputada (1936), após o falecimento do titular. Bertha Lutz reivindicou a ampliação dos direitos das mulheres, propôs a criação do Departamento Nacional da Mulher8, e também propôs o Estatuto da Mulher - PL 736/37, visando a igualdade de direitos entre homens e mulheres. A decretação do fechamento do Congresso Nacional e a instalação do regime do Estado Novo por Getúlio Vargas (1937-1945), interrompeu a trajetória política das mulheres no Brasil. Após a ditadura Vargas, os partidos se reestruturaram, iniciou-se o processo Constituinte, mas não se elegeu nenhuma mulher para a legislatura de 1946 a 1950. Nas legislaturas seguintes as mulheres apareceram timidamente. Dos 326 deputados federais eleitos na legislatura de 1950 a 1954, apenas uma era mulher, Ivete Vargas, sobrinha-neta de Getúlio Vargas, representando 0,3\% do total. Na legislatura seguinte (1954-1958), além de Ivete, Nita Costa foi eleita, "elevando" para $0,6 \%$ a representatividade. Na legislatura de 1958-1962 e de 1962-1966, somente Ivete Vargas foi eleita. A legislatura de 1966-1970, portanto, em plena ditadura militar, teve seis deputadas $(1,4 \%)$, sendo que dentre estas, três eram esposas de deputados cassados pelo Regime. Desse grupo, cinco se destacaram nas críticas à ditadura, e tiveram seus mandatos cassados em 1969 com base no AI5. A partir de 1970, novamente cai o

\footnotetext{
${ }^{8}$ Carlota de Queiroz se manifestou contrariamente à proposta.
} 
número de mulheres na Câmara: uma na legislatura de 1970-1975; uma de 19751979; aumentando para quatro de 1979-1983.

Se a década de 1970 foi a década da solitária representação políticopartidária feminina, foi também uma década de intensa participação política das mulheres, especialmente do movimento feminista, do movimento estudantil, operário e camponês. A repressão contra as mulheres que militaram na resistência à ditadura se deu tanto por serem da resistência quanto por serem mulheres e “estarem onde não deveriam estar":

Aquelas que se opuseram à ditadura foram ferozmente atacadas, acumulando diante de seus torturadores dois crimes: o da ação política na oposição ao regime e o da transgressão das representações dominantes de gênero, lançando-se a fazer "coisas de homem", renegando sua natureza. Portanto, as mulheres que ousaram enfrentar o regime militar foram duramente reprimidas, e os próprios procedimentos de tortura utilizados contra elas precisam ser analisados em perspectiva de gênero.(...) Os agentes do Estado se sentiram legitimados para praticar o que poderíamos chamar de "tortura corretiva" como punição para o fato das mulheres estarem onde "não deveriam estar". (SOUZA, 2014b, p. 168 e 170).

A participação das mulheres na política partidária começa a ser incrementada no expirar da ditadura e a partir do processo Constituinte. Na legislatura de 1983-1987, oito mulheres, dentre 479 deputados, atuavam na Câmara (1,6\%), e na legislatura de 1987-1991, 29 mulheres (5,1\% dos 487) foram eleitas deputadas, das quais três eram suplentes. Nessa legislatura foi eleita a primeira mulher negra como deputada federal: Benedita da Silva9. É nesse período que as deputadas iniciam atuações articuladas em torno dos direitos das mulheres, e a bancada feminina começa a se organizar como tal. Nos pleitos seguintes a presença feminina na política continuou aumentando, mas sempre a passos lentos: 30 deputadas (1991-1995); 42 deputadas (1995-1999). A primeira lei que estabeleceu reserva de vagas para mulheres, foi a Lei 9.100, de 1995, que definiu que os partidos reservassem 20\% das vagas de suas candidaturas para mulheres.

\footnotetext{
${ }^{9}$ Benedita da Silva foi também a primeira mulher negra eleita vereadora na cidade do Rio de Janeiro, senadora e governadora (era vicegovernadora do RJ, mas com a renúncia do então governador, ela assume o posto).
} 
Em 1997, a Lei 9.504, ampliou para 30\% essa reserva, mas não exigiu a obrigatoriedade do preenchimento das vagas. Na legislatura de 1999-2003, foram eleitas 40 deputadas federais ${ }^{10}$. No período seguinte (2003-2007) foram eleitas 52 deputadas, caindo para 46 na legislatura de 2007-2011. Na legislatura de 20112015, 45 mulheres foram eleitas, e outras que eram suplentes assumiram no decorrer do período, perfazendo um total de 52 deputadas.

A atual legislatura, que compreende o período de 2015-2019, conta com 51 deputadas federais, não chegando a 10\% dos 513 parlamentares eleitos. Destas, nenhuma foi eleita por Alagoas, Sergipe, Paraíba, Mato Grosso e Espírito Santo. O Rio de Janeiro elegeu seis deputadas, sendo o Estado com maior representação feminina na Câmara Federal. Das 51 deputadas, apenas três se declaram pretas, o que também indica o caráter étnico-racial da representação política no Brasil. O percentual de mulheres negras na Câmara Federal não atinge 10\% da bancada feminina, e se considerarmos o total de deputados e deputadas federais, as mulheres que se declaram pretas correspondem a $0,6 \%$, enquanto as que se declaram pardas somam ínfimos 1,6\%. Isso soma $2,2 \%$ do conjunto de parlamentares. Esse percentual é bem menor do que o também baixo percentual de deputados federais negros, que é de cerca de $18 \%$ do total eleito em 2014 ${ }^{11}$. A subrepresentação de mulheres e homens negros na Câmara tem implicações sobre a definição das pautas prioritárias dessa casa, que tende a ser menos sensível para as reivindicações desses segmentos, especialmente no que tange às mulheres negras. Como afirma Carole Pateman, "as estruturas sexuais e raciais de poder obstruem de forma sistemática a cidadania formal das mulheres” (2010, p.30).

Além das insuficientes políticas em defesa dos direitos das mulheres e do combate às desigualdades de gênero, a morosidade na aprovação de projetos voltados para a promoção da plena cidadania feminina e as ações de obstrução das

\footnotetext{
${ }^{10}$ Uma delas, Ceci Cunha, foi assassinada antes de tomar posse como deputada.

${ }^{11}$ Dados adicionais podem ser encontrados no site da Câmara Legislativa, no boletim eletrônico Notícias da Câmara (MACEDO, 2014)
} 
propostas submetidas são indicadores de que as mulheres não têm sido prioridade no fazer político da Câmara dos Deputados.

Um dos segmentos mais combativos e que nas últimas legislaturas tem se promovido por empunhar a bandeira contra o que se convencionou chamar de “ideologia de gênero" (SOUZA, 2014a) e contra os direitos reprodutivos das mulheres, é a Frente Parlamentar Evangélica (FPE), que reúne parlamentares que se declaram evangélicos e que se apresentam como defensores da família, da moral e dos bons costumes.

\section{A Frente Parlamentar Evangélica}

No ano 2000, o Censo (IBGE) registrou que o número de brasileiros e brasileiras que se declaravam evangélicos havia saltado de 9\% para 15,4\% da população, o que correspondia a 26,2 milhões de evangélicos no país, majoritariamente pentecostais. O Censo seguinte (2010) confirmou o crescimento, sendo que os que se declararam evangélicos superaram os 42,3 milhões ${ }^{12}$, numa proporção de $22,2 \%$ da população brasileira, um contingente que não podia ser ignorado, inclusive no âmbito da política.

O crescimento do número de pessoas que se declaram evangélicas, a forte presença na mídia e a ascensão política, são aspectos que se entrelaçam na consolidação da presença pública dos evangélicos. Sua participação políticopartidária é um aspecto da visibilidade contemporânea desse segmento. Especialmente a partir do processo constituinte de 1986, quando foram eleitos 32 deputados autodeclarados evangélicos, dos quais 18 se declaravam pentecostais (PIERUCCI, 1996). Durante a década de 1990, a presença pública dos evangélicos, particularmente da Igreja Universal do Reino de Deus e da Assembleia de Deus, se fez sentir, dentre outras coisas, por sua forte inserção na mídia, fruto das

\footnotetext{
${ }^{12}$ Destes, 12,3 milhões se declararam assembleianos.
} 
concessões negociadas no processo constituinte. O mote "crente não se mete em política” (PIERUCCI, 1996, p. 163) aos poucos dá lugar à política do "irmão vota em irmão" (SYLVESTRE, 1986). É com essa mudança de mentalidade em relação à política, na percepção da via político-partidária como via de defesa de seus interesses religioso-institucionais, que os evangélicos vão se mobilizando e se fazendo visíveis na esfera política, atuando de forma alinhada no Congresso. Um dos frutos dessa mobilização foi a criação, em 2003, da Frente Parlamentar Evangélica - FPE, que desde então tem se declarado como a legítima representante dos evangélicos na política ${ }^{13}$. Ela é composta por senadores e deputados federais, e também por ex-parlamentares (membros colaboradores), conforme previsto em seu estatuto (FPE, 2003).

$\mathrm{Na}$ legislatura de 2015-2019 foram eleitos 72 deputados e deputadas autodeclarados evangélicos ${ }^{14}$, mas como a FPE não atualizou sua página quanto aos novos membros, não é possível saber se todos os eleitos efetivamente participam da Frente, pois há parlamentares que não estão alinhados com a mesma.

A atuação de parcela significativa dos parlamentares evangélicos tem sido marcada pela defesa dos interesses das instituições religiosas que representam, pela defesa do que denominam de moral cristã, pela luta contra o que interpretam como ameaça à liberdade religiosa etc. O pressuposto da ação desses políticos seria

\footnotetext{
${ }^{13}$ Sem dúvida não existe um coletivo evangélico homogêneo, como as estratégias de marketing dos candidatos tentam afirmar. A heterogeneidade teológica e política dos mais de 42 milhões de pessoas que se declaram evangélicas se faz sentir nos resultados das urnas que ficaram muito abaixo da expectativa alardeada, por exemplo, em relação ao candidato à presidência Pastor Everaldo, do PSC. Enquanto o partido e seus apoiadores falavam em adesão de $12 \%$ do eleitorado, o pastor recebeu 780.513 votos, correspondentes a $0,75 \%$ dos votos válidos. Essa heterogeneidade também pode ser vista nas diversas manifestações de pessoas e instituições evangélicas que se posicionaram contra a nomeação de Marco Feliciano para a presidência da Comissão Nacional de Direitos Humanos. Em um dos documentos solicitando a sua saída, mas de 150 lideranças evangélicas solicitaram a sua saída da CDHM, contando, inclusive, com a assinatura de pastores da Assembleia de Deus. Além disso, é importante destacar que os deputados e deputadas se distribuem em cerca de 20 diferentes denominações evangélicas, sem contar os diferentes ministérios das igrejas Assembleias de Deus, o que indica ser complexo querer definir qualquer tipo de representação homogênea e reducionista: "os evangélicos". Em vários casos há ainda aqueles e aquelas que estão na política não necessariamente para representarem as instituições religiosas às quais declaram estar vinculados, mas por um projeto pessoal.

${ }^{14}$ Concordamos com a seleção feita por Magali do Nascimento Cunha das listas da FPE e do DIAP. A FPE elencou os nomes de 79 deputados evangélicos eleitos no pleito de 2014, enquanto o DIAP listou 82 evangélicos eleitos. Cunha descarta os nomes de Cesar Halum, Weliton Prado, Hissa Abrahão, Marcelo Belinati, Sandro Alex, Sérgio Reis, Damião Feliciano, Eduardo Bolsonaro e Celso Russomano, pois os mesmos não se declaram evangélicos. Daí chegar à lista de 72 nomes (CUNHA, 2014).
} 
legislar conforme “os propósitos de Deus”. No Estatuto da Frente, artigo $2^{\circ}$. III, lêse:

Procurar, de modo contínuo, a inovação da legislação necessária à promoção de políticas públicas, sociais e econômicas eficazes, influindo no processo legislativo a partir das comissões temáticas existentes nas Casas do Congresso Nacional, segundo seus objetivos, combinados com os propósitos de Deus, e conforme Sua Palavra15. (FPE, 2003).

Resguardado o fato de que não há uma homogeneidade política e ideológica entre os parlamentares evangélicos, assim como entre os evangélicos de forma geral, vemos predominar na FPE um discurso de legitimação da ação política desses parlamentares, que passa pela evocação da identidade e das crenças religiosas.

Uma rápida visita ao site da $\mathrm{FPE}^{16}$ demonstra o conteúdo de ordem políticoreligiosa que lhe confere identidade. As chamadas das notícias postadas no site revelam a afirmação da identidade religiosa do grupo: "Frente Parlamentar Evangélica Celebra Ceia no Congresso Nacional”; "Cerca de 200 igrejas destruídas em onda de violência anti-cristã"; "Frente Parlamentar faz culto a Deus e homenageia à mulher na Câmara dos Deputados”. Outras notícias disponíveis no site indicam para a ênfase da FPE em temas relacionados especialmente aos direitos reprodutivos e aos direitos da população LGBT: "Exército brasileiro critica projeto que criminaliza a homofobia"; "Projeto que criminaliza homofobia será arquivado"; "Parlamento francês aprova lei: pagar sexo é crime"; "Personalidades brasileiras estarão presentes no mais famoso evento mundial pela vida, a Marcha pela Vida, de Washington”. Os links disponíveis no site da FPE também são bastante sugestivos: Observatório Legislativo da Família; Marcha pela Vida Contra o Aborto; Movimento Nacional da Cidadania pela Vida - Brasil sem aborto, dentre outros.

\footnotetext{
${ }^{15}$ Grifo da autora.

${ }^{16}$ A Frente Parlamentar Evangélica (2015) tem seu próprio site.
} 
É especialmente com essa ênfase que deputados, deputadas e senadores vinculados à FPE tem se destacado no cenário político brasileiro. Apelando para as representações dominantes de gênero e para seus preceitos religiosos, os parlamentares da FPE, em sua maioria, têm sido fortes opositores a quaisquer projetos de lei que visem a ampliação dos direitos da população LGBT e dos direitos reprodutivos das mulheres, especialmente no que tange à descriminalização do aborto. Esses parlamentares têm sido também responsáveis pela elaboração e/ou defesa de projetos que obstaculizam avanços em relação aos direitos acima mencionados, bem como projetos que visam retroceder em relação a direitos já adquiridos.

A instrumentalização da religião pela política e da política pela religião, nos faz perguntar pelas consequências sobre as possibilidades de conquista da cidadania plena das mulheres. Conforme demonstram Shahra Razavi, Anne Jenichen e Jacqueline Heinen, uma série de ações políticas da parte de religiosos e instituições religiosas contra os direitos reprodutivos das mulheres tem acontecido nos mais diversos países:

Os direitos reprodutivos das mulheres, em particular, que alguns podem julgar como adquiridos, são objeto de questionamentos recentes em vários países. [...] Na Rússia, a Duma, rejeitou, por pouco, um projeto de lei apresentado pela Igreja Ortodoxa, para se fazer o pagamento do aborto e para introduzir cláusulas restritivas visando desencorajar as mulheres a recorrer ao aborto. Na Suíça, uma iniciativa dos católicos extremistas para se tirar o aborto da lista de doenças cobertas pelo seguro médico, será submetida ao voto popular em 2012, a fim de alterar a Constituição17. Na Polônia, onde o aborto é de fato quase impossível há quase vinte anos, a Diète rejeitou por uma pequena maioria um projeto de lei apresentado por movimentos religiosos visando proibi-lo totalmente. No México, após a despenalização do aborto pelo Estado federal em 2008, uma campanha apoiada pela Igreja católica levou mais da metade dos Estados mexicanos a adotar leis que protegem a vida desde a concepção, o Supremo Tribunal recusou-se a declarar este tipo de cláusula inconstitucional - com o apoio aberto do governo conservador. Nos Estados Unidos, onde os ataques do

\footnotetext{
${ }^{17}$ O artigo foi escrito em 2012. O resultado da votação, realizada em 09 de fevereiro de 2014, foi pela manutenção do reembolso, pelo seguro obrigatório de saúde, dos procedimentos para a interrupção voluntária da gravidez.
} 
pró-vida se multiplicam a cada ano, quase uma centena de alterações de várias ordens têm sido adotadas pelas legislaturas de vinte e quatro Estados para restringir as condições de acesso ao aborto (2012, p. 6-7) ${ }^{18}$.

No Brasil, dentre os parlamentares mais combativos em relação aos direitos sexuais e reprodutivos na atualidade, estão o Deputado pastor Marco Feliciano (PSC-SP), ex-presidente da Comissão de Direitos Humanos e Minorias, vinculado à Assembleia de Deus; o deputado pastor João Campos (PSDB-GO), atual presidente da FPE, também da Assembleia de Deus; e Eduardo Cunha (PMDB-RJ), atual presidente da Câmara dos Deputados, também da Assembleia de Deus ${ }^{19}$. Cunha e Campos estão em seu $4^{\circ}$. mandato, enquanto Feliciano cumpre seu $2^{\circ}$. mandato.

Figurando na lista de membros da FPE, esses deputados têm conquistado ampla projeção na mídia e na política, estando à frente de uma série de projetos diretamente relacionados aos direitos das mulheres. Eduardo Cunha, por exemplo, é o autor do Projeto de Decreto Legislativo PDC 1487/2014, que "susta a eficácia da Portaria $\mathrm{n}^{\mathrm{o}}$ 415, de 21 de maio de 2014 do Secretário de Atenção à Saúde do Ministério da Saúde, que inclui o procedimento interrupção da gestação/ antecipação terapêutica do parto previstas em lei e todos os seus atributos na Tabela de Procedimentos, Medicamentos, Órteses e Materiais Especiais do SUS”20. Em outras palavras, o parlamentar reivindica que esse procedimento não conste na tabela do Sistema Único de Saúde, o que prejudica o atendimento das mulheres que buscam os serviços públicos para a interrupção da gravidez nos casos previstos por lei. A Portaria é de 21 de maio de 2014, e a apresentação do PDC data de 27 de

\footnotetext{
18 “Les droits reproductifs des femmes, en particulier, que d'aucuns pouvaient juger acquis, font l'objet de remises en cause récentes dans plus d'un pays. En Russie, la Douma a repoussé de justesse un projet de loi soutenu par l'Église orthodoxe pour rendre l'avortement payant et introduire des clauses restrictive visant à dissuader les femmes d'y avoir recours. En Suisse, une initiative portée par les catholiques extrémistes pour radier l'avortement des prestations de l'assurance maladie sera soumise au vote populaire en 2012 afin de modifier la Constitution. En Pologne où l'avortement est de facto quasiment impossible depuis près de vingt ans, la Diète n'a rejeté qu'à une courte majorité un projet de loi porté par les mouvements religieux visant à l'interdire totalement. Au Mexique où, suite à la dépénalisation de l'avortement par l'État fédéral de Mexico, en 2008, une campagne appuyée par l'Église catholique a conduit plus de la moitié des États mexicains à adopter des lois protégeant la vie dès la conception, la Cour suprême a refusé de déclarer ce type declauses inconstitutionnel - avec l'appui ouvert du gouvernement conservateur. Aux États-Unis, où les attaques des pro-vie sont légion depuis des années, près d'une centaine d'amendements de divers ordres ont été adoptés par les législatures de vingt-quatre États pour restreindre les conditions d'accès à l'avortement". (2012, p. 6-7) Tradução da autora.

${ }^{19}$ Cunha era filiado à igreja Sara a Nossa Terra, mas em 2015 se filiou à Assembleia de Deus, Ministério Madureira.

${ }^{20}$ Ver Projeto de Decreto Legislativo do Deputado Pastor Marco Feliciano, 2012.
} 
maio de 2014. O relator da Comissão de Seguridade Social e Família rejeitou o PDC que foi arquivado pela mesa diretora da Câmara dos Deputados em 31 de janeiro de 2015, tendo sido desarquivado, por requerimento de Cunha, no dia 10 de fevereiro de 2015 .

Dentre suas proposições, João Campos apresentou o requerimento de instituição de CPI (RCP 21/2013) visando a investigação da "existência de interesses e financiamentos internacionais para promover a legalização do aborto no Brasil, prática tipificada como crime no Código Penal Brasileiro, em seus arts. 124 a 127". Organizações como a Fundação Ford, a Fundação MacArthur e a própria ONU, que apoiam iniciativas voltadas para a promoção da saúde das mulheres e de seus direitos sexuais e reprodutivos, foram acusadas pelo deputado de promoverem atividades criminosas no país ${ }^{21}$. O requerimento foi indeferido, tendo sido arquivado pela mesa diretora da Câmara em 28 de janeiro de 2015.

O deputado Marco Feliciano, além de apresentar uma série de proposições que afetam direitos da população LGBT, também tem um histórico de ações dedicadas à obstrução de direitos das mulheres. Esse é o caso do Projeto de Decreto Legislativo PDC 565/2012, apresentado em o9 de junho de 2012. Nele o parlamentar solicita a sustação "da aplicação da decisão do Supremo Tribunal Federal proferida na Arguição de Descumprimento de Preceito Fundamental no 54 , que declara não ser crime a "antecipação terapêutica de parto" de anencéfalos" 22 . $O$ projeto foi arquivado em 31 de janeiro de 2015, mas foi desarquivado pela atual mesa diretora da Câmara dos Deputados no dia 11 de fevereiro de 2015.

Essas e outras ações indicam que os direitos sexuais e reprodutivos estão na pauta da Frente Parlamentar Evangélica, e que suas proposições em relação a esses temas tendem a impor dificuldades no avanço da superação dos mecanismos de opressão de gênero que afetam as mulheres nos seus direitos fundamentais.

\footnotetext{
${ }^{21}$ BRASIL, 2013.

${ }^{22}$ FELICIANO, 2012.
} 
Na Câmara dos Deputados, a discussão dos direitos das mulheres tem sido feita majoritariamente por homens, pois eles constituem a maioria dessa casa legislativa. A menor presença de mulheres nas instâncias políticas tem consequências sobre a manutenção e sobre a ampliação dos seus direitos. Isso não significa que o simples fato de haver mulheres na esfera política seja suficiente para a conquista de direitos para esse segmento, mas a diversificação das vozes é um primeiro passo para a diversificação das pautas, para a ampliação das interlocuções, para a percepção de outras demandas etc. Na FPE, os homens são maioria e suas proposições têm se demonstrado pouco sensíveis à percepção das mulheres como sujeitos de direitos. As mulheres que se declaram filiadas à Frente, têm participado das ações da Bancada Feminina para a ampliação da participação das mulheres na política, mas em geral ainda tendem a acompanhar os posicionamentos conservadores de seus colegas que são também os posicionamentos de seus grupos religiosos.

\section{Mulher, evangélica e deputada}

Dos 72 deputados declaradamente evangélicos da atual legislatura, dez são mulheres (14\%). O total de deputadas federais eleitas para a legislatura de 20152019 soma 51 parlamentares 23 , o que significa que 20\% das mulheres da Câmara Federal se declaram evangélicas. O crescimento das candidaturas femininas de forma geral, seja pela obrigatoriedade das cotas, seja pela maior participação econômica das mulheres, seja pela luta feminista para que as mulheres participem das escolhas públicas do país, também repercutiu no campo evangélico. O número de candidaturas de mulheres evangélicas, porém, não se consolidou nas urnas. $\mathrm{Na}$ legislatura 2011-2014, havia nove mulheres autodeclaradas evangélicas, e a legislatura atual conta com dez. Apesar do fato das mulheres serem ampla maioria em todas as denominações evangélicas (IBGE, 2010), isso não tem se revelado fator de ampliação significativa de sua participação na esfera política.

\footnotetext{
${ }^{23}$ Para a atual legislatura foram também eleitas 13 senadoras.
} 
Dentre as evangélicas eleitas, Benedita da Silva (PT-RJ), de origem assembleiana e atualmente declarada presbiteriana renovada, cumpre seu quarto mandato como deputada federal, e Bruna Furlan (PSDB-SP), declarada membro da Congregação Cristã no Brasil, cumpre seu segundo mandato. As outras oito deputadas estão cumprindo o seu primeiro mandato na Câmara Federal: Julia Marinho (PSC-PA), Eliziane Gama (PPS-MA), e Geovania de Sá (PSDB-SC), se declaram membros da Assembleia de Deus; Tia Eron (PRB-BA) e Rosângela Gomes (PRB-RJ), se declaram da Igreja Universal do Reino de Deus; Christiane Yared (PTN-PR) é pastora da Igreja Evangelho Eterno; Clarissa Garotinho (PR-RJ), se declara participante da Igreja Presbiteriana e Rejane Dias (PT-PI), da Igreja Batista.

Se pensarmos em termos de distribuição geográfica das candidatas, três delas são do Rio de Janeiro, e os estados de São Paulo, Santa Catarina, Paraná, Maranhão, Bahia, Piauí e Pará elegeram apenas uma representante do sexo feminino. Os demais estados não elegeram nenhuma mulher evangélica para a Câmara Federal. Nenhum estado do Centro-Oeste elegeu deputada evangélica.

O pentecostalismo predomina entre os deputados e deputadas que se declaram evangélicos, e a Assembleia de Deus é a denominação preponderante entre eles e elas. Isso é curioso, uma vez que a representação dominante do pentecostalismo como expressão religiosa que limita a autonomia das mulheres e as restringe à esfera doméstica não se confirmaria, pelo menos não de maneira estanque. A religião tem propiciado uma maior participação das mulheres na esfera pública. A trajetória religiosa e a trajetória política das parlamentares muitas vezes se encontram. Muito embora seu engajamento religioso nem sempre seja reconhecido na forma de ascensão na hierarquia das igrejas das quais participam, as transformações socioculturais em relação às representações de gênero têm, de alguma forma, modificado a postura das instituições religiosas acerca da inserção das mulheres na esfera pública. Isso pode significar muitas coisas como uma efetiva mudança da mentalidade institucional em relação ao que é "espaço 
permitido" e "espaço interditado" para as mulheres, ou tem a ver simplesmente com o pragmatismo político de determinadas instituições religiosas e partidos políticos, que lançam candidaturas femininas evangélicas para não deixarem descobertos os 30\% da cota para mulheres, perdendo assim a possibilidade dessa representação na Câmara.

O fato é que os avanços das mulheres em termos socioeconômicos e políticos, e os interesses eclesiásticos de projeção política, têm forçado as fronteiras da esfera política, que lentamente se torna mais permeável à presença de mulheres evangélicas. E têm forçado as fronteiras da religião, que se vê diante do imperativo da participação política feminina e da consequente extrapolação dos limites cultural-religiosos impostos às mulheres.

O que tem acontecido nos pleitos eleitorais, porém, é que as candidaturas femininas não têm encontrado receptividade no meio evangélico. Uma parte considerável das campanhas eleitorais dos candidatos evangélicos se deu por meio do acionamento da identidade religiosa, e essa estratégia parece não ter sido tão eficaz para as mulheres como o foi para os homens. Dos 20 deputados federais mais votados nas últimas eleições, quatro são evangélicos: Pastor Marco Feliciano24 (40.), Clarissa Garotinho ( $7^{\circ}$. ), Pastor Eurico (19 .) e Eduardo Cunha (20 ${ }^{\circ}$.). Clarissa Garotinho foi a única mulher a figurar na lista dos 20 mais votados. O público alvo das campanhas eleitorais de Feliciano, Eurico e Cunha foram os evangélicos. O apelo para a identidade religiosa que, em tese, teria como princípio a defesa da moral e dos bons costumes, foi a tônica dos candidatos, e funcionou como estratégia de arregimentação de eleitores. No caso de Clarissa, o capital simbólico é outro: o nome de família. Filha de Anthony Garotinho e Rosinha Garotinho, Clarissa utilizou o nome político do pai e da mãe para o ingresso na

\footnotetext{
${ }^{24}$ Aqui aparecem os nomes conforme registrados no STE.
} 
política ${ }^{25}$. É claro que as competências individuais desses parlamentares não podem ser descartadas, mas o dado da herança religiosa ou familiar não pode ser negligenciado como recurso eleitoral dos candidatos em questão. O ponto é que Clarissa Garotinho não foi votada especialmente por ser evangélica, como no caso dos outros três deputados. Um aspecto a ser desenvolvido e que não cabe nesse artigo é justamente o da receptividade de candidatas mulheres pelas e pelos fieis evangélicos, perguntando-nos se haveria ou não o reconhecimento, por parte dos adeptos e adeptas de denominações evangélicas, de que a política é também "lugar de mulher".

As deputadas que se declaram evangélicas têm apresentado uma série de proposições ${ }^{26}$, mas nem todas têm se preocupado em fazer proposições relacionadas aos direitos das mulheres. A deputada Bruna Furlan²7, apresentou na atual legislatura, 27 proposições entre indicações, requerimentos e projetos de lei. Destes, apenas o REQ 60/2015, apresentado no dia 14 de abril de 2015, se destina à discussão de um tema especificamente voltado para as mulheres: a prescrição e os efeitos decorrentes do uso de anticoncepcionais hormonais. O Requerimento é para que se realize audiência pública para debater esse tema. A proponente principal é a deputada Geovânia de Sá, também evangélica. Bruna Furlan também não teve a luta pelos direitos das mulheres como prioridade da legislatura anterior (20112014). Durante seus quatro anos como deputada federal, além da Indicação INC5803/2014, que sugere a criação de programa de apoio à implantação de creches noturnas em todo o país, ela apresentou a INC-2614/2012 para a construção de equipamento público multifuncional para atendimento às mulheres. As duas propostas foram arquivadas por ocasião do final da $54^{\mathrm{a}}$. Legislatura, e na

\footnotetext{
${ }^{25}$ Veremos isso também com Bruna Furlan, filha de Rubens Furlan, que já foi vereador, prefeito, deputado estadual e deputado federal, e que apareceu ao lado de Bruna com bastante frequência durante as campanhas de 2010 e de 2014. Bruna utilizou de maneira discreta o recurso à identidade evangélica, pois apesar de ser neta de cooperador da Congregação Cristã no Brasil e afirmar que segue os valores da igreja, se valeu especialmente do nome do pai durante as duas campanhas. Ela ingressou na carreira política já como deputada federal, e foi eleita para o seu primeiro mandato com 270.611 votos, e no segundo mandato teve menor receptividade, alcançando 178.606 votos.

${ }^{26}$ Todas as informações sobre as proposições apresentadas pelas deputadas foram extraídas do site da Câmara dos Deputados (http://www2.camara.leg.br/deputados). O acesso foi feito nos meses de abril, maio e início de junho de 2015.

${ }^{27}$ Bruna Furlan aparece no site da FPE como membro da mesma, conforme acesso em 22 abr. 2015.
} 
solicitação do desarquivamento das proposições de sua autoria no início da $55^{\mathrm{a}}$. Legislatura, Furlan somente solicitou o desarquivamento dos Projetos de Lei, deixando arquivadas as duas Indicações acima citadas. A deputada não apresentou nenhum Projeto de Lei destinado às mulheres durante o mandato anterior e até o presente momento de seu segundo mandato. Dentre as funções que ocupou na $54^{\mathrm{a}}$. legislatura, foi membro titular da Comissão de Seguridade Social e Família - CSSF, no breve período de 29 de maio de 2013 a 28 de agosto de 2013. Na atual legislatura a deputada não participa de nenhuma comissão em que o debate mais direto sobre os direitos das mulheres seja prioridade.

A deputada federal Benedita da Silva, vem de uma longa trajetória política que se iniciou em termos político-partidários em 1983, quando de sua eleição como vereadora da cidade do Rio de Janeiro. Ela é a deputada evangélica que acumula mais anos de atuação político-partidária, tendo sido vereadora, deputada federal por quatro mandatos, senadora, vice-governadora do RJ e governadora interina desse mesmo estado. Inicialmente declarada membro da Assembleia de Deus, Benedita da Silva migrou recentemente para a Igreja Presbiteriana Renovada. Negra, nascida em favela, empregada doméstica, a ascensão política da parlamentar está relacionada à sua militância junto a movimentos sociais, inicialmente na Associação de Favelas do Estado do Rio de Janeiro. A pertença religiosa também foi importante para sua consolidação política, mas é importante ressaltar que a Assembleia de Deus na época em que Benedita da Silva foi eleita vereadora, se manifestava publicamente de forma contrária ao envolvimento político da igreja. Mesmo no início de 1985, quando da posse de Tancredo Neves e do encontro de lideranças assembleianas com o presidente, o editorial do Mensageiro da Paz, jornal oficial da igreja, trazia a seguinte mensagem para seus leitores e leitoras:

O compromisso da Igreja no contexto da sociedade é de tal monta que sua influência precisa ampliar os horizontes e alcançar, inclusive, os altos escalões do governo [...] portanto, o diálogo iniciado entre os evangélicos e 
o próximo governo está longe de ser um envolvimento político o que não interessa a Igreja como instituição, ainda que individualmente, os crentes possam ter o direito de fazer suas opções $^{28}$ (KESSLER, 1985, p.2)

Dentre as diversas atividades da parlamentar, há várias voltadas para os direitos da população negra de forma geral, das quais não trataremos aqui, e algumas estão relacionadas aos direitos das mulheres. Na atual legislatura ela é membro titular da Comissão de Seguridade Social e Família - CSSF; e membro titular da Comissão Especial PL 6583/13 (5/3/2015 - 10/3/2015), que trata do Estatuto da Família. Em legislaturas anteriores, Benedita da Silva já havia sido membro titular da Comissão de Seguridade Social e Família - CSSF. Sobre a participação em conselhos, atualmente ela é conselheira do Conselho Nacional dos Direitos da Mulher, e já foi membro (líder comunitária) do Conselho Nacional de Mulheres do Brasil (1984). Na legislatura atual, até agora Benedita da Silva propôs apenas o Projeto de Resolução de Alteração do Regimento, PRC 2/2015, em que solicita a alteração do regimento interno da Câmara Federal para que a presidência da mesma seja exercida por uma mulher todo dia 08 de março. Em 26 de março de 2013, a deputada apresentou Projeto de Lei PL-5238/2013, que altera a Consolidação das Leis do Trabalho para aplicar seus preceitos às pessoas que trabalham como empregadas domésticas, que são majoritariamente mulheres. A deputada apresentou diversos requerimentos relacionados à PEC 47810, que trata dos direitos das trabalhadoras e dos trabalhadores domésticos (REQ 8/2012; REQ 9/2012; REQ 130/2011; REQ 4/2011;REQ 6/2011). Também assinou, junto com Iara Bernardi e Janete Rocha Pietá, dentre outros, o Requerimento RQ 258/2013 para a realização de Seminário Internacional sobre Mulher e Poder Político na América Latina e Caribe. Foi autora do Requerimento REQ 6776/2013 que solicita a análise urgente do PL 6653/2009, de autoria da deputada Alice Portugal, que trata da igualdade de oportunidade para mulheres e homens no mercado de trabalho. No REQ 6777/2013, Benedita da Silva pede urgência na análise do PL 4857/2009, de autoria de Valtenir Pereira, e que visa garantir as mesmas

\footnotetext{
${ }^{28}$ Grifo da autora
} 
oportunidades para mulheres e homens, criando mecanismos para o enfrentamento e prevenção de toda forma de discriminação contra as mulheres. Em 28 de junho de 2012, a deputada assina com os deputados João Campos (pastor), pastor Marco Feliciano, pastor Eurico, e outras/os não vinculados/as à FPE, o REQ 237/2012, que requer a realização de seminário para identificar e debater sobre os programas de "valorização da família" desenvolvidos no âmbito do poder público e também da iniciativa privada. Também com deputados da FPE e outros parlamentares, Benedita assinou o Requerimento de Informação RIC2381/2012, que requer que o Ministério da Saúde preste informações sobre os Termos de Cooperação e Convênios destinados a pesquisas sobre aborto e descriminalização do aborto no Brasil. O Projeto de Lei PL-2436/2011, acrescenta parágrafo único ao artigo 14 da Lei 9096, visando que os cargos em órgãos de direção e deliberação dos partidos, sejam preenchidos de forma paritária entre os sexos. A regulamentação dos critérios de concessão de licença paternidade, foi objeto da preocupação da deputada, que em 9 de novembro de 2011, redigiu o REQ 3717/2011, requerendo a tramitação conjunta do PL 879/2011 e 6753/2010, que tratam do assunto.

A deputada de primeiro mandato, Julia Marinho (PSC-PA) ${ }^{29}$, além de realizar campanha em que a identidade religiosa foi utilizada como recurso eleitoral, também teve a seu favor o fato de ser casada com o ex deputado Zequinha Marinho, que atualmente é o vice-governador do Pará. A deputada concedeu entrevista por ocasião de sua posse, afirmando que está assumindo o mandato de deputada federal para dar continuidade aos mandatos de seu marido30. Julia Marinho é suplente na Comissão de Seguridade Social e Família. Dos três primeiros projetos de lei submetidos na Câmara pela parlamentar, todos no dia o6 de março de 2015, um deles, o PL 620/2015 propõe alteração da Lei 8069, para vedar a adoção conjunta por casal homoafetivo. As demais proposições estão relacionadas à atividade da parlamentar como presidente da Comissão de

\footnotetext{
${ }^{29}$ Assim como Bruna Furlan, Julia Marinho ingressou na política já como deputada federal.

${ }^{30}$ DEPUTADA JULIA MARINHO, 2015.
} 
Integração Nacional, Desenvolvimento Regional e da Amazônia - CINDRA, desde 04 de março de 2015. Até o presente momento, Julia Marinho não apresentou proposições voltadas para os direitos das mulheres.

Eliziane Gama (PPS-MA) é membro titular da Comissão de Defesa do Consumidor, da Comissão de Segurança Pública e Combate ao Crime organizado, suplente da Comissão de Meio Ambiente e Desenvolvimento Sustentável, e membro da Comissão Parlamentar de Inquérito - CPI Petrobrás. Antes de se tornar deputada federal, foi deputada estadual pelo Maranhão, no período de 2007 a 2014. Esse ingresso na carreira política teve o apoio da Assembleia de Deus, que em 2006 a indicou como candidata em sua Convenção Estadual no Maranhão (Convenção Estadual das Assembleias de Deus no Estado do Maranhão CEADEMA). A maioria de suas proposições está relacionada com a CPI da Petrobrás, da qual é membro titular. Eliziane Gama não apresentou nenhuma proposição relacionada aos direitos das mulheres até o momento.

Antes de ser deputada federal, Geovânia de Sá (PSDB-SC) foi vereadora na cidade de Criciúma-SC. A parlamentar ganhou projeção em sua cidade como musicista e cantora gospel e por sua atuação na Assembleia de Deus, além de ter tido o deputado Marco Feliciano como cabo eleitoral31. Dentre suas atividades como deputada, Geovânia é membro titular da Comissão de Seguridade Social e Família, e membro suplente da Comissão de Educação, da Comissão de Trabalho, de Administração e Serviço Público e da Comissão de Cultura. A deputada é também membro da Comissão Especial PEC 473/01, que visa que a escolha de ministros e ministras do STF seja feita de maneira alternada entre a presidência da República e o Congresso Nacional. Dentre suas proposições, Geovânia de Sá assina, juntamente com Celso Russomano e outros, o REQ 2020/2015 que requer urgência na votação do PDC 18/2015, de autoria do deputado Jair Bolsonaro, e do PDC 17/2015, de autoria de Marco Feliciano, que sustam as Resoluções no. 11/2014 e 12/2015, do Conselho Nacional de Combate à Discriminação e Promoção dos

\footnotetext{
${ }^{31}$ Veja vídeo da campanha da Deputada Geovânia de Sá (2012).
} 
Direitos de Lésbicas, Gays, Travestis e Transexuais - CNCD/LGBT. A Resolução 11/2014, estabelece parâmetros para que constem nos boletins de ocorrência os itens “orientação sexual”, identidade de gênero" e "nome social”. A Resolução 12/2015, estabelece que as instituições e redes de ensino devem garantir o reconhecimento da identidade de gênero de travestis e transexuais, seja no uso do nome social, no uso de banheiro ou uniforme, etc. A parlamentar também assina o REQ 60/2015, que solicita que se realize audiência pública para a discussão da prescrição e dos efeitos decorrentes do uso de anticoncepcionais hormonais.

Tia Eron (PRB-BA) - iniciou sua carreira política como vereadora, apoiada pela Igreja Universal do Reino de Deus, tendo cumprido quatro mandatos nessa função. Em 2014 foi eleita como deputada federal pela Bahia. Das comissões das quais participa, é titular apenas da Comissão de Ciência e Tecnologia, Comunicação e Informática - CCTCI. Tia Eron apresentou propostas voltadas para os interesses das mulheres como o Projeto de Lei PL-1180/2015, que estabelece que seja entregue às mulheres que estão sob medida protetiva de urgência, o "botão do pânico”. Ainda sobre violência contra as mulheres, a parlamentar apresentou o REQ 10/2015, que convida diversas autoridades federais e estaduais que lidam com os direitos das mulheres, para falarem à Comissão de Constituição e Justiça sobre o PL 5555/2013, que dispõe sobre a criação de mecanismos para o enfrentamento de ofensas e violências diversas cometidas contra as mulheres pela internet e outros meios. O PL 1710/2015, também de sua autoria, dispõe sobre o apoio às atividades das mulheres marisqueiras. Sobre os direitos das parlamentares, o PL 953/2015 proposto por ela estabelece que caso uma candidata eleita seja mulher, sua suplente também deverá ser mulher, para que se mantenha a proporcionalidade obtida no processo eleitoral.

Rosângela Gomes (PRB-RJ) foi vereadora de Nova Iguaçu, RJ, por três mandatos, tendo sido deputada estadual no período de 2011 a 2015. Foi vendedora ambulante e trabalhou em serviços gerais. Se envolveu com a causa da juventude pobre da Baixada Fluminense, por meio da Igreja Universal do Reino de Deus. A 
deputada foi lançada e apoiada pela IURD. Esse é seu primeiro mandato como deputada federal, sendo $3^{\mathrm{a}}$. procuradora adjunta da Procuradoria da Mulher, e membro titular das comissões de Seguridade Social e Família; e de Relações Exteriores e Defesa Nacional. Atualmente é a vice-presidente da Comissão de Direitos Humanos e Minorias. Além de palestrar em eventos sobre mulheres imigrantes, a parlamentar apresentou diversas proposições relacionadas aos direitos das mulheres. De sua autoria, a Indicação INC 292/2015, sugere que o Ministério da Educação providencie transporte escolar para filhos e filhas de mulheres presidiárias detidas em prisões que não contem com berçário ou creche. As Indicações INC 501/2015 e INC 502/2015, de sua autoria, sugerem que se implante nas cidades de Angra dos Reis - RJ e Nova Friburgo - RJ, respectivamente, uma unidade da Casa da Mulher Brasileira como aparelho de apoio, enfrentamento e proteção às mulheres em situação de violência. Rosângela Gomes também é autora do INC 71/2015, que sugere que a Secretaria de Comunicação Social da Presidência da República realize campanhas de repúdio à violência contra as mulheres. Dentre os Projetos de Lei propostos pela deputada, o PL 1842/2015, dispõe sobre crimes de estupro e atentado violento ao pudor, visando separar esses dois tipos de crime, que na Lei 12015/2009, foram fundidos num único tipo, o que tende a reduzir a pena dos agressores. Ainda em relação à violência contra as mulheres, o PL 345/2015 apresentado por Rosângela Gomes, e retirado posteriormente, objetivava implantar o monitoramento eletrônico do agressor para acompanhar o cumprimento das medidas protetivas das mulheres. Os PLs 347/2015 e 348/2015, apresentados pela deputada, também dispõem sobre a violência doméstica contra mulheres. A parlamentar também é autora do PL 346/2015, que dispõe sobre a autonomia financeira dos programas de incentivo à participação política das mulheres, objetivando que os recursos do Fundo de Participação Partidária, sejam destinados a esse fim, e sejam movimentados em conta específica. Ainda no quesito "participação política das mulheres”, Rosângela Gomes propôs o PL 349/2015, que visa combater todas as formas de violência e discriminação político-eleitorais que tenham o intuito de impedir ou restringir a 
ação política das mulheres.

Christiane Yared (PTN-PR) ingressou na política diretamente como deputada federal. Esse é o seu primeiro mandato, e se tornou conhecida por meio de sua militância pela paz no trânsito, após seu filho morrer em acidente automobilístico provocado pelo então deputado estadual Fernando Ribas Carli Filho, que dirigia em alta velocidade e estava bêbado. Yared fundou o Instituto Paz no Trânsito, que presidiu de 2010 a 2014. A deputada é membro titular da Comissão de Seguridade Social e Família, e é suplente na Comissão Especial PL 6583/13 - Estatuto da Família. Dentre as proposições da parlamentar, o Requerimento REQ 56/2015 solicita que se realize uma audiência pública com profissionais da área para debater sobre a endometriose, desde as formas de diagnóstico aos possíveis tratamentos da mesma.

Clarissa Garotinho (PR-RJ) foi deputada estadual pelo Rio de Janeiro no período de 2011 a 2014. Como já apontamos, a deputada carrega consigo o nome político de família "Garotinho", como trunfo político, e seu pai, Anthony Garotinho, e sua mãe, Rosinha Garotinho, ambos políticos experientes, foram seus principais apoiadores, participando ativamente de sua campanha eleitoral. Esse é o seu primeiro mandato como deputada federal, e dentre suas atividades como parlamentar, Clarissa é membro titular e presidente da Comissão de Viação e Transportes. A deputada é membro titular da Comissão Especial PL 7446/14, pelo aprimoramento dos direitos da criança, e é suplente da Comissão Especial PL 6583/13, do Estatuto da Família, dentre outras comissões. Dentre as proposições da parlamentar está o PL 606/2015, que garante que as mulheres a partir dos 40 anos de idade tenham direito à realização de mamografia. Essa foi a única proposição da deputada até agora que se relaciona aos direitos das mulheres.

Rejane Dias (PT-PI) está em seu primeiro mandato como deputada federal, tendo atuado como deputada estadual no período de 2011 a 2014. A parlamentar ingressou na política com o apoio do marido, Wellington Dias, que foi governador 
do Piauí no período de 2003 a 2010. Regiane Dias pediu licença de seu mandato como deputada federal para assumir, em 23 de março de 2015, o cargo de Secretária de Estado da Educação e Cultura do Piaúi. Durante sua rápida passagem pela Câmara, a deputada apresentou duas proposições voltadas para os direitos das mulheres no que tange ao enfrentamento da violência. O Projeto de Lei 689/2015, visa conter a criminalidade contra as mulheres por meio da criação de Núcleos Investigativos de Feminicídio distribuídos por todo o país. Já o PL 788/2015, propõe que haja acompanhamento psicossocial do agressor como mecanismo para coibir a violência doméstica e familiar contra as mulheres.

Os dados levantados acerca da origem e das proposições das parlamentares evangélicas são reveladores. As parlamentares explicitamente apoiadas pela igreja Assembleia de Deus, e declaradamente membros da mesma, Júlia Marinho, Eliziane Gama e Geovânia de Sá, até o momento não apresentaram qualquer proposição voltada para os direitos das mulheres. Duas das parlamentares, Júlia Marinho e Geovânia de Sá, apresentaram proposições contrárias aos direitos LGBT, acompanhando a orientação da igreja no que se refere ao seu posicionamento quanto aos direitos desse segmento. As parlamentares, até o momento pelo menos, não têm priorizado o debate sobre os direitos das mulheres, o que reforça a posição da igreja quanto à secundariedade das mulheres em suas fileiras, sejam eclesiásticas ou políticas.

As deputadas Bruna Furlan e Clarissa Garotinho, herdaram o nome político de seus pais e Rejane Dias, assim como Júlia Marinho, herdaram o nome político de seus maridos. Esse é um indicador de que talvez a receptividade de mulheres na esfera política ainda esteja atrelada a uma concepção patriarcal acerca da legitimidade da ação política feminina, que passaria pelo aval de homens, no caso, seus pais ou maridos. Bruna Furlan, Clarissa Garotinho e Rejane Dias apresentaram, até agora, apenas uma proposição relacionada aos direitos das mulheres. As denominações às quais as parlamentares declaram pertencer, Congregação Cristã no Brasil, Presbiteriana e Batista, respectivamente, têm pouco 
ou nenhum envolvimento com a política partidária, não possuindo ingerência sobre as atividades das parlamentares.

Apesar de pastora, Christiane Yared raramente evoca essa condição em suas manifestações públicas. Ela elegeu-se deputada federal pela militância em favor de um trânsito melhor. O deflagrador de tal militância, como já apontamos, foi a morte de seu filho em 2009 em acidente provocado por um deputado. A sensibilização do eleitorado se deu também por sua condição de mãe que perdeu um filho. Mais uma vez a legitimidade e reconhecimento da presença pública das mulheres se pauta, de uma ou outra forma, nas representações de gênero que tal participação evoca. Yared apresentou apenas uma proposição relacionada à saúde das mulheres até o presente momento.

As três deputadas negras, Benedita da Silva, Tia Eron e Rosângela Gomes, são do Rio de Janeiro e são as que mais propuseram Projetos de Lei, Requerimentos e Indicações voltadas para os direitos das mulheres. Nenhuma delas vem de tradição familiar política, portanto, não herdaram o espólio político de seus pais ou maridos. Além disso, suas igrejas, enquanto instituições, interferem pouco ou nada em decisões que envolvam a discussão dos direitos das mulheres, o que dá relativa autonomia de ação às parlamentares. Benedita da Silva, apesar de suas raízes assembleianas, teve autonomia em relação à igreja, pois sua militância social e política se construíram a partir de sua condição de mulher negra moradora de favela. A deputada declara professar atualmente o presbiterianismo renovado, que na prática não tem ingerência sobre suas ações. Tia Eron e Rosângela Gomes declaram ser da Igreja Universal do Reino de Deus. A IURD tem investido na candidatura de seus adeptos e adeptas, definindo estratégias e orientando campanhas a partir de suas demandas institucionais, mas permite maior autonomia destes em suas decisões como parlamentares, desde que garantidos os seus interesses. 


\section{Conclusão}

Considerando os levantamentos realizados, o que se verifica é que as parlamentares cuja ingerência da igreja em seus mandatos é maior, passaram seus primeiros seis meses de atividade política sem demonstrar preocupação com o contingente feminino, não apresentando qualquer proposição nesse sentido. No caso das deputadas cuja ingerência religiosa não se faz sentir de maneira tão explícita, mas que advêm de classes mais abastadas, são brancas e são herdeiras do nome político de seus pais ou maridos, também os direitos das mulheres parecem ser de interesse secundário. O mesmo se verifica com Christiane Yared, que apesar de não herdar nome político de familiar, é de classe média, branca e não está

sujeita a interferências diretas da igreja da qual é pastora. Já as deputadas que construíram carreira política na militância social com segmentos marginais da sociedade e que advêm desses mesmos segmentos, tiveram o apoio de suas igrejas sim, especialmente Tia Eron e Rosângela Gomes, mas têm tido relativa independência em sua agência política, pois as igrejas às quais declaram pertencer não pautam sua agência pelo menos nesse quesito.

A interseccionalidade de gênero, raça/etnia, classe e religião precisa ser considerada com mais profundidade nas pesquisas sobre a participação das mulheres evangélicas na política. Se a esfera política se apresenta como esfera limitadora da participação das mulheres, os caminhos que têm se apresentado a essas mulheres são o do "capital familiar patriarcal" e o do "capital religioso" que carregam. A religião tem se apresentado como possibilidade de acesso das mulheres a essa esfera, porém, em muitos casos, não sem cobrar seu preço. Além das limitações da socialização familiar, cultural e religiosa de gênero, a ingerência religiosa em alguns mandatos de deputadas tem sido um grande limitador da identificação dessas parlamentares com as demandas das mulheres. Porém, é também pela via da religião, que mulheres negras de periferia estão ascendendo na 
política. Das três deputadas federais autodeclaradas negras, três são evangélicas, o que corresponde a $100 \%$ desse contingente. Essa é uma questão que precisa ser mais aprofundada em análise posterior.

\section{REFERÊNCIAS}

ALVES, Branca Moreira. Ideologia e feminismo. Petrópolis: Vozes, 1980.

AZEVEDO, Débora Bithiah de; RABAT, Marcio Nuno. Palavra de Mulher: oito décadas do direito ao voto. Brasília, Câmara dos Deputados: Edições Câmara, 2012.

BRASIL. Câmara dos Deputados. Requerimento de Instituição de CPI No (Dos Senhores João Campos, Salvador Zimbaldi e outros). Disponível em: de 2013. <http://www.camara.gov.br/proposicoesWeb/prop_mostrarintegra?codteor=1075429\&fil ename=Tramitacao-RCP+21/2013> . Acesso em: 17 mar. 2015.

BRASIL. Portal Brasil. Em 1933, Carlota Pereira Queiroz se tornou a primeira mulher eleita no Brasil, como deputada federal. 30 agosto 2010. Disponível em: <http://www.brasil.gov.br/old/copy_of_imagens/sobre/cidadania/especial-eleicoes2010/galeria-de-historia/carlota-pereira-queiroz-a-primeira-mulher-eleita/view $>$. Acesso em: 15 maio 2015.

BUTLER, J. Problemas de gênero: feminismo e subversão da identidade. Rio de Janeiro: Civilização Brasileira, 2003

BUTLER, Judith. Bodies That Matter: On the Discursive Limits of "Sex". New York: Routledge, 1993.

CAMPANHA GEOVANIA DE SÁ. Marcos Feliciano. Campanha Geovania de Sá para Vereadora. Vídeo. Disponível em: <https://www.youtube.com/watch?v=2oH6XIz1eSk>. Acesso em: 02 abr. 2015.

COSTA, Ana Alice. As donas no poder: mulher e poder na Bahia. Salvador: Assembleia Legislativa da Bahia,1988.

CUNHA, Magali do Nascimento. Evangélicos e as eleições de 2014: listagem final dos/as deputados/as evangélicos/as eleitos/as e um balanço pós-5 de outubro. Blog Mídia, Religião e Política: São Bernardo do Campo, 12 out. 2014. Disponível em: <http://midiareligiaopolitica.blogspot.com.br/2014/10/evangelicos-e-as-eleicoes-2014listagem.html>. Acesso em: 12 abr. 2015. 
DATASENADO; PROCURADORIA ESPECIAL DA MULHER. Mulheres na Política. Brasília, 2014. Disponível em:

<http://www12.senado.leg.br/senado/procuradoria/publicacao/cartilha-mulheres-napolitica>. Acesso em: 05 abr. 2015.

DEPUTADA JÚLIA MARINHO dará continuidade ao trabalho de Zequinha Marinho naCâmara. Disponível em: <https://www.youtube.com/watch?v=aB12vGJSERA >. Acesso em: 02 abr. 2015.

FELICIANO, Deputado Pastor Marco. Projeto de Decreto Legislativo n. , de 2012 (Do Sr. Pastor Marco Feliciano). Disponível em:

<http://www.camara.gov.br/proposicoesWeb/prop_mostrarintegra?codteor=990106\&file name $=$ Tramitacao-PDC+565/2012>. Acesso em: 17 mar. 2015.

FPE - Frente Parlamentar Evangélica. Estatuto da FPE. Brasília, setembro de 2003. Disponível em: <http://www.fpebrasil.com.br/portal/index.php/a-frente/estatuto-dafep>. Acesso em: 30 mar. 2015.

FRENTE PARLAMENTAR EVANGÉLICA - Portal da FPE. Disponível em: <http://www.fpebrasil.com.br/portal/>. Acesso em: 10 maio 2015.

GROSSI, Mirian P.; HEILBORN, Maria L.; RIAL, Carmen. Entrevista com Joan Wallach Scott. Revista Estudos Feministas, Florianópolis, v. 6, n.1, p. 114-124, 1998.

INTER-PARLIAMENTARY UNION. Women in Parliament: 20 years in review. Disponível em: <http://www.ipu.org/pdf/publications/WIP20Y-en.pdf> Acesso em: 05 abr. 2015 .

\section{KESSLER, Nemuel. Tancredo Neves e as Assembleias de Deus (Editorial).} Mensageiro da Paz, ano LV, n. 1174, fev. 1985.

MACEDO, Ana Raquel. Homens brancos representam 80\% dos eleitos para a Câmara. Câmara Notícias. Brasília, 09 out. 2014. Disponível em: <http://www2.camara.leg.br/camaranoticias/noticias/POLITICA/475684-HOMENSBRANCOS-REPRESENTAM-71-DOS-ELEITOS-PARA-A-CAMARA.html>. Acesso em: 04 mar. 2015 .

MACHADO NETO, Afonso C. (coord.). Sociedade e história do Brasil. Os primeiros tempos da República. Brasília: Instituto Teotônio Vilela, 2000.

OKIN, Susan Moller. Gênero, o público e o privado. Revista Estudos Feministas, Florianópolis, v. 16, n. 2, p. 305-332, 2008.

PASSARINHO, Nathalia e ALEGRETTI, Laís. Se bate como homem, mulher tem que apanhar como homem, diz deputado. G1, Brasília, o6 de maio de 2015. Disponível em: <http:/g1.globo.com/politica/noticia/2015/05/se-bate-como-homem-mulher-tem-queapanhar-como-homem-diz-deputado.html>. Acesso em: 07 maio 2015. 
PATEMAN, Carole. Garantir a cidadania das mulheres: a indiferença e outros obstáculos. Revista Crítica de Ciências Sociais, Coimbra, n. 89, p. 29-40, junho de 2010.

PATEMAN, Carole. O Contrato Sexual. São Paulo: Paz e Terra, 1993.

PIERUCCI, Antônio Flávio. Representantes de Deus em Brasília: a bancada evangélica na constituinte. In: PIERUCCI, Antônio Flávio; PRANDI, Reginaldo (org.). A realidade social das religiões no Brasil: religião, sociedade e política. São Paulo: Hucitec, 1996.

PITKIN, Hanna F. Justice: on relating private and public. Political Theory, USA, v. 9, n.3, p. 327-352, Aug. 1981.

PORTO, Walter Costa. Dicionário do voto. Brasília: UnB, 200o, p. 427-436.

RAZAVI, Shahra; JENICHEN, Anne; HEINEN, Jacqueline. Mariage fatal entre religion et politique: source d'écueils pour l'égalité des sexes. In: HEINEN, Jacqueline; RAZAVI, Shahra. Religion et politique: les femmes prises au piège. Paris: L'Harmattan, 2012, p. 5-26.

ROURE, Agenor de. Constituinte Republicana. Brasília: Senado Federal, 1979.

SCOTT, Joan W. A cidadã paradoxal: as feministas francesas e os direitos do homem. Florianópolis: Mulheres, 2002.

SCOTT, Joan W. Gênero: uma categoria útil de análise histórica. Educação e Realidade, v. 16, n. 2, Porto Alegre, jul./dez. 1990.

SOUZA, Sandra Duarte de. "Não à ideologia de gênero!" A produção religiosa da violência de gênero na política brasileira. Estudos de Religião, São Bernardo do Campo, v. 28, n. 2, p. 188-204, dezembro de 2014.

SOUZA, Sandra Duarte de. Ditadura militar brasileira: a propósito da agência política de mulheres cristãs. In: SOUZA, Sandra Duarte de; SANTOS, Naira Pinheiro dos (org.).

Estudos Feministas e Religião: tendências e debates. Curitiba/São Bernardo do Campo: Prismas/Universidade Metodista de São Paulo, 2014b, p. 149-171.

SYLVESTRE, Josué. Irmão vota em irmão: os evangélicos, a Constituinte e a Bíblia. Brasília: Pergaminho, 2006.

TRIBUNAL SUPERIOR ELEITORAL - TSE. Presidente do TSE anuncia aumento de 5,17\% no eleitorado brasileiro. Disponível em: <http://www.tse.jus.br/noticiastse/2014/Julho/presidente-do-tse-anuncia-aumento-de-5-17-do-eleitorado-brasileiro>. Acesso em 14 abr. 2015. 